Journal of Chemical and Pharmaceutical Research, 2016, 8(8):915-921

Research Article

ISSN : 0975-7384

CODEN(USA) : JCPRC5

\title{
Synthesis and electrical properties of ZnO-ITO and Al-ITO thin film by spin coating technique through sol gel process
}

\author{
Hardeli $^{1 *}$, Hary Sanjaya ${ }^{2}$ and Rahadian Zainul ${ }^{3}$ \\ ${ }^{1,3}$ Physical Chemistry Laboratory, Padang State University, Padang, Indonesia \\ ${ }^{2}$ Analytical Chemistry Laboratory, Padang State University, Padang, Indonesia
}

\begin{abstract}
In this research we has investigated synthesis and electrical properties of ITO (Indium Tin Oxide) thin layers doping Aluminum (Al) and $\mathrm{ZnO}$ with spin-coating technique through sol-gel process and calcined at $\pm 550{ }^{\circ} \mathrm{C}$ for 1 hour. Effect of $\mathrm{Al}$ and $\mathrm{ZnO}$ doping on the conductivity of ITO with $0 \%, 1 \%, 3 \%$ and $5 \% \mathrm{w} / \mathrm{v}$ dopant concentration and the number of coating (4 and 5 layers) has reported. ITO-Al has 2 phases, these are rhombohedral and cubic, the crystal size is $67.31 \mathrm{~nm}$. Meanwhile, ITO-ZnO are rhombohedral, cubic (bixbyite) and hexagonal (wurtzite), with crystallite size value was $67.4 \mathrm{~nm}$. The surface morphology data indicated film thickness was $3.4 \mu \mathrm{m}$ (ITO-Al) and $0.974 \mathrm{~nm}(\mathrm{ITO}-\mathrm{ZnO})$. The electrical properties shows that the optimum film in 4 layers coating with the addition of $5 \%$ doping value was $17 \mathrm{k} \Omega / \mathrm{cm}^{2}$ (ITO-Al) and 5-layered by addition of $5 \%$ of doping $\mathrm{ZnO}\left(80.800 \mathrm{k} \Omega / \mathrm{cm}^{2}\right)$. Meanwhile, ITO-Al thin film with 4 layers coating without doping was $9.331 \mathrm{k} \Omega / \mathrm{cm}^{2}$, and for ITO-ZnO (5 layers) coating without doping was $11.796 \mathrm{k} \Omega / \mathrm{cm}^{2}$. Al and $\mathrm{ZnO}$ doping decrease the electrical conductivity of ITO.
\end{abstract}

Keywords : ITO, Sol-gel, Spin-coating, Thin film, Al and $\mathrm{ZnO}$ doping

\section{INTRODUCTION}

Indium Tin Oxide thin film, has a high transparency in the visible region and low electrical resistivity(1). ITO thin film composed of $\mathrm{In}_{2} \mathrm{O}_{3}$ doped with $\mathrm{SnO}_{2}$. Based on Alam research the addition of $10 \% \mathrm{SnO}_{2}$ can improve the conductivity of ITO thin film, so that it has a low resistivity(2). Thus, ITO thin film has a band gap larger than 3.5 $\mathrm{eV}$ and has transparent properties in visible light region(3). ITO film is usually in the form of amorphous and have low conductivity at low temperatures, so high heating temperature needed to modify the optical properties, electrical, and crystal structure. The resistivity will be reduced by increasing the calcination temperature above $400^{\circ} \mathrm{C}(4)$. The higher the calcination temperature, the electrical conductivity will be better.

Transparent Conducting Oxide (TCO) glass is a material coated by a metal oxide, which has optical transparency in the area of the electromagnetic spectrum and have electrical conductivity. ITO (Indium Tin Oxide) is a type of TCO which has transparency properties and high electrical conductivity(5). The combination of these properties causes ITO thin film has been used in the development of today's technology such as LCD (Liquid Crystal Display), LED (Light Emitting diodes), solar cells, optoelectronics, gas sensors(6). Improved the performance of ITO thin film becomes an important topic to explore both on an industrial scale and on a laboratory scale considering the necessary for the use of the ITO thin film in daily life.

One of the aspects that can improve the performance of the ITO thin film is the addition of doping, such as the insertion of other atoms in a semiconductor that aims to change the value of conductivity(7) Zainul et al reported Al metal have potentially as negative charge carrier in surface of material(8), so that can considerate as doping in 
material. Doping acts to minimize the width of the band gap so that the energy required for the excitation of electrons from the valence band to the conduction band getting smaller(9). Some of metals and oxides can use as dopant, such as $\mathrm{Fe}, \mathrm{Cu}, \mathrm{Ni}, \mathrm{Al}, \mathrm{ZnO}, \mathrm{TiO}_{2}$ and almost all oxides. In this research, $\mathrm{ZnO}$ and $\mathrm{Al}$ metal use as dopant for ITO.

$\mathrm{ZnO}$ used as doping in this study because according to Suprayogi, $\mathrm{ZnO}$ is a compound that is not toxic, readily available, resistant to radiation and high termal stability(10). In addition, $\mathrm{ZnO}$ has a wide band gap of $3.37 \mathrm{eV}$ (at a temperature of $300 \mathrm{~K})(11)$. The addition of a new band of $\mathrm{ZnO}$ on ITO band gap will cause a decrease in the amount of energy required to electrons excitation from the valence band to the conduction band, so that it can increase the electrical conductivity of ITO(9).

The ITO film deposition using metal doping of group IIIA, among the group IIIA metal is aluminum (Al) (12). The function of aluminum doping is to increasing the value of the conductivity of ITO by occupying space in the structure of ITO and substituting Al atoms in the structure of ITO. Conductivity value of aluminum is $3.8 \times 107$ ( $\Omega$ $\mathrm{m})-1$. According to Rosa (2009) aluminum is very easy to join and produce a low barrier (12).

In order to produce high electrical conductivity of the ITO doped $\mathrm{ZnO}$ and $\mathrm{Al}$ thin film, there are several parameters that should be modified include the formation of a material element composition, crystal size and thickness of the coating(13). The composition of the elements is one of the factors that determine the success of the preparation of the ITO doped $\mathrm{ZnO}$ and $\mathrm{Al}$ thin film, therefore in this study the influence of the composition of which will be seen by varying the doping concentration of $\mathrm{ZnO}$ and $\mathrm{Al}$ on the ITO precursor. Intake of the $\mathrm{Al}$ and $\mathrm{ZnO}$ doping concentration variation refers to the study Hoong, these are $0 \%, 1 \%, 3 \%$, and $5 \%(14)$.

Thin film preparation are also greatly influenced by the thickness layer factor. Preliminary research that has been conducted by the author and supported by research of Daoudi showed that the number of coating layers effect on the electrical conductivity produced in which the use of 1, 2, 3, 4, 5 layers obtained better conditions at 4 and 5 layers(15). The results of the study being a reference for the ITO doped $\mathrm{ZnO}$ and $\mathrm{Al}$ thin film number of coating variation.

There are several deposition methods for the preparation of thin film, including facing target sputtering, dc magnetron sputtering, sol-gel process $(10 ; 16 ; 17)$. Sol-gel method have the advantages among others due to the deposition process is simple, the cost of making thin film is cheaper, can be used for the manufacture of thin film with a large area without the use of expensive and complex equipment(18). Sol-gel method consist of some coating techniques, these are spin-coating, dip-coating (19) and spray-coating(20). Comparison of the three techniques, the author uses spin-coating technique in the preparation of the ITO doped $\mathrm{ZnO}$ and $\mathrm{Al}$ thin film because it has the advantage of relatively cheaper cost, more homogeneous, lower process temperatures(21). Spin-coating merupakan suatu teknik untuk mendeposisikan lapisan tipis yaitu melalui percepatan larutan pada substrat yang diputar. Proses spin-coating dilakukan dengan menggunakan alat spin-coater berkecepatan tinggi dalam jangka waktu tertentu. Semakin cepat putaran, akan diperoleh lapisan tipis yang semakin homogen dan tipis(22).

To determine the properties of the ITO doped $\mathrm{ZnO}$ and $\mathrm{Al}$ thin film is carried out characterization by SEM, XRD and digital multimeter. SEM is used to observe the surface morphology and thickness of the film layer. XRD is used to specify the existent phases and crystal size. The resistivity of the ITO doped $\mathrm{ZnO}$ and Al thin film is measured using a digital multimeter, where the measurement is performed under direct sunlight.

\section{EXPERIMENTAL SECTION}

\section{A. Equipment and Materials}

The equipments used were beaker glass, measuring cylinder, spatula, sprayer bottle, pipette, analytical balance, pincers, conventional spin-coater, glass substrates of $10 \times 25 \times 1 \mathrm{~mm}$, volumetric flask, volumetric pipette, neck erlenmeyer, ultrasonic cleaner, oven, furnace, XRD, SEM, digital multimeter.

The materials used were distilled water, 96\% ethanol, $21 \%$ nitric acid, ammonia p.a, $\left(\mathrm{Zn}\left(\mathrm{CH}_{3} \mathrm{COO}\right)_{2} .2 \mathrm{H}_{2} \mathrm{O}\right)$, $\mathrm{InCl}_{3} \cdot 4 \mathrm{H}_{2} \mathrm{O}$, acetyl acetone p.a, $\mathrm{SnCl}_{2} \cdot 2 \mathrm{H}_{2} \mathrm{O}$, iso-propanol p.a, acetone p.a, polyvinyl pyrrolidone (PVP), nitrogen gas, ethanol 96\%, nitrogen gas, Acetyl acetone, methanol pa, iso-propanol, polyvinyl pyrrolidone (PVP) and $\mathrm{AlCl}_{3} \cdot 6 \mathrm{H}_{2} \mathrm{O}$ 


\section{B. Glass Substrates Cleaning}

The glass substrates cleaning procedures has been adapted from Kesim procedure(20). Substrates must be free of grease and dust. Glass substrates were treated ultrasonically for $120 \mathrm{~min}$ with a row in soapy water, acetone, ethanol, and finally distilled water and dried at $\pm 110^{\circ} \mathrm{C}$ for \pm 60 min after cleaning.

\section{Preparation of ITO Precursor}

The preparation procedures has been adapted from Yang(23). ITO precursor made from mixing In and Sn in molar ratio 9:1. $\mathrm{InCl}_{3} \cdot 4 \mathrm{H}_{2} \mathrm{O}$ concentration maintained at $0.5 \mathrm{M}$ was dissolved in acetyl acetone and incubated for \pm 8 hours at $\pm 60{ }^{\circ} \mathrm{C} . \mathrm{SnCl}_{2} \cdot 4 \mathrm{H}_{2} \mathrm{O}$ dissolved in iso-propanol. In and $\mathrm{Sn}$ solution was mixed at room temperature and added $\mathrm{PVP}$ as an adhesive agent.

\section{Preparation of $\mathrm{ZnO}$ Doping}

The preparation of $\mathrm{ZnO}$ doping has been adapted from working procedure of $\mathrm{Maddu}(24) .\left(\mathrm{Zn}\left(\mathrm{CH}_{3} \mathrm{COO}\right)_{2} \cdot 2 \mathrm{H}_{2} \mathrm{O}\right)$ was dissolved in $10 \mathrm{ml}$ of ethanol. $2 \mathrm{ml}$ of ammonia was added while stirring. $21 \% \mathrm{HNO}_{3}$ was added step by step until reaching $\mathrm{pH}=6$. Variations were made in the doping concentration of $1 \%, 3 \%$ and $5 \% \mathrm{w} / \mathrm{v}$.

\section{E. Preparation ITO doped ZnO Thin Film}

The ITO doped $\mathrm{ZnO}$ sol deposited using a soft brush and small puddle of a fluid resin on the center of a substrate, then rotated in the spin-coater for 3 minutes at $500 \mathrm{rpm}$. Heating is done for \pm 120 minutes at $\pm 80^{\circ} \mathrm{C}$. Coating is done by 4 and 5 layers. To form metal oxide, the glass substrate calcined at $\pm 550{ }^{\circ} \mathrm{C}$ for \pm 60 minutes. The ITO doped $\mathrm{ZnO}$ thin film ready to characterized.

F. Preparation of Al Doping and ITO doped Al Thin Film

The preparation of $\mathrm{Al}$ doping has been adapted from working procedure of Maddu(24). The process ITO doped Al thin film as shown in figure 1.

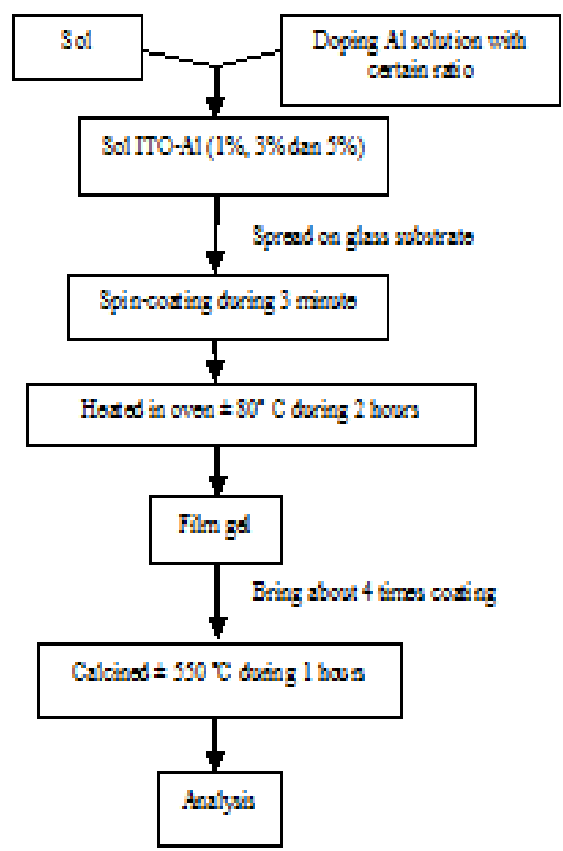

Figure 1. Systematics Procedure

\section{RESULTS AND DISSCUSSION}

The XRD pattern of ITO doped $\mathrm{ZnO}$ and $\mathrm{Al}$ was confirmed with ICSD-ICDD (Inorganic Structure Database International Center for Diffraction Data), there are three type of crystals of ITO doped $\mathrm{ZnO}$ and two type for ITO doped Al. They are rhombohedral, cubic(bixbyite) and hexagonal (wurtzite) for ITO/ZnO, and rhombohedral and cubic (bixbyite) for ITO/Al. It is indicated of the thin layer growing with polycrystalline structure.

From Figure 2 there is a highest peak at $30.6501^{\circ} 2 \theta$ position, the peaks of ITO-Al 5\% [International Centre for Diffraction Data - Inorganic Crystal Structure Database (ICSD-ICDD)] was obtain trought the Scherrer equation, 
crystal size is $67.31 \mathrm{~nm}$. For ITO/ZnO, the somes highest peaks at $2 \theta=21.48^{\circ}, 30.56^{\circ}, 35.44^{\circ}, 51.01^{\circ}, 60.65^{\circ}$, and the highest peak at $2 \theta=30.56^{\circ}$ with sharp intensity was indicated of formation ITO-doped Al.

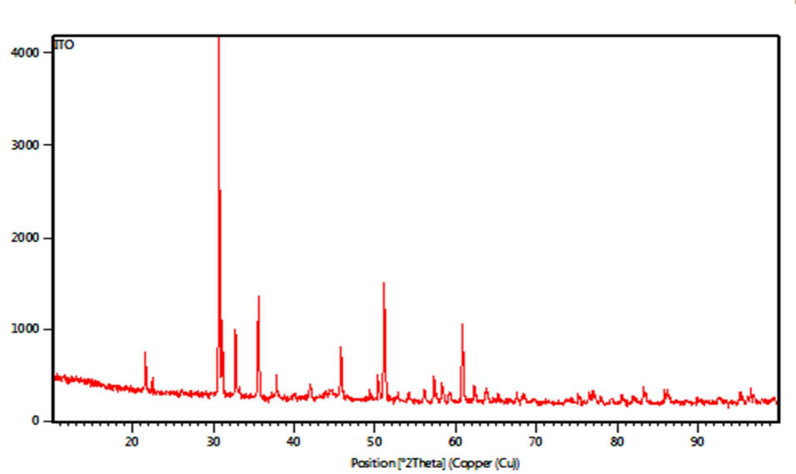

(a)

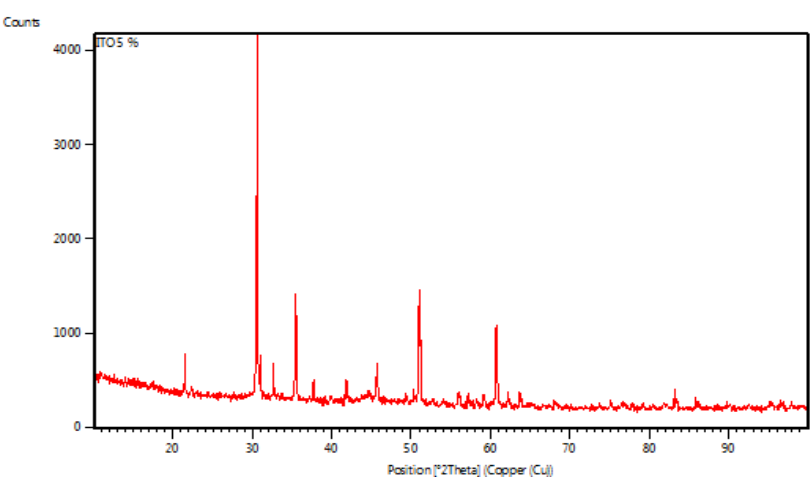

(b)

Figure 2. XRD from ITO doping with (a) ZnO $5 \%$ and (b) Al $5 \%$
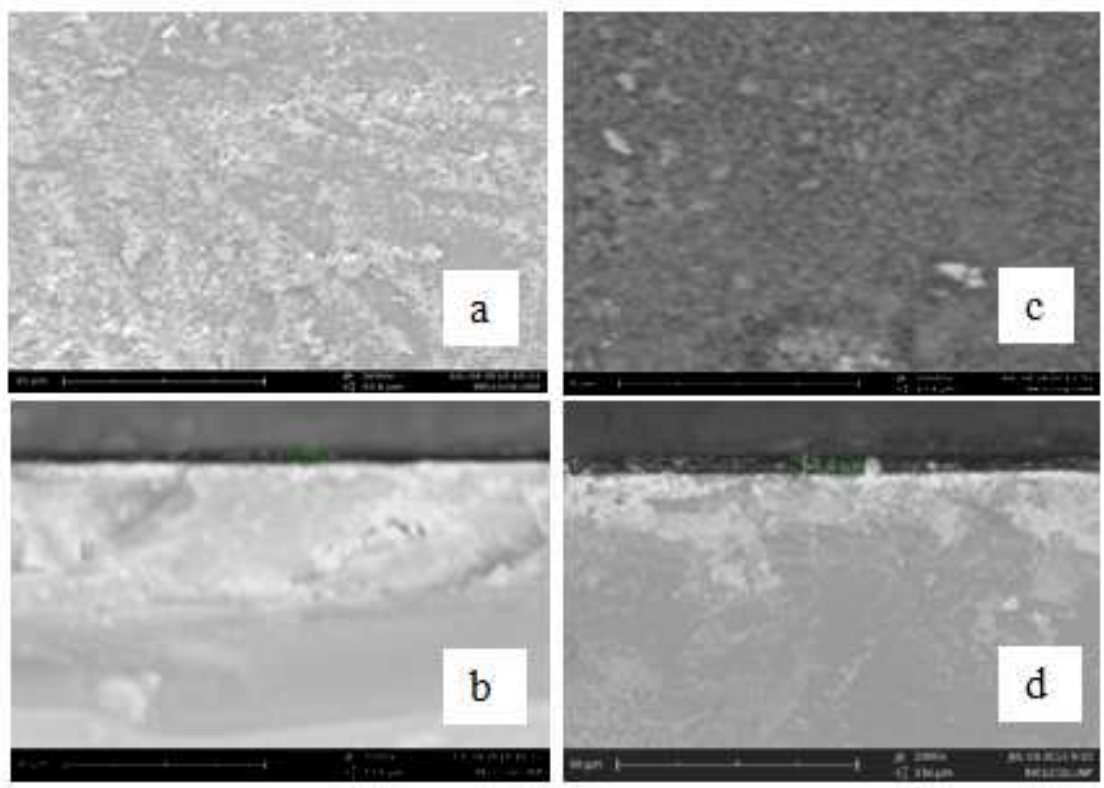

Figure 3. SEM images of the surface of the ITO-ZnO $5 \%$ thin film after being calcinated at $500^{\circ} \mathrm{C}$ with magnification (a) 5000 times, (b) 2000 times and surface of the ITO-Al $5 \%$ thin film after calcinating at a temperature of $550^{\circ} \mathrm{C}(\mathrm{c}) 5000$ times, (d) 2000 times magnification

SEM characterization results shown in Figure 3 (a) and (c) shows that the thin layer of ITO-ZnO 5\% and ITO-Al 5\% by particles deposited ITO-ZnO 5\% and ITO-Al 5\% hardly spread but still formed aggregates or clusters of crystals ITO-ZnO 5\% and ITO-Al 5\% and some particle size. SEM results showed the limitations of cracks and formation of aggregates on the surface of deposition results. It was by the presence of air bubbles on the surface of the substrate during the hydrolysis process of drying or low temperature, the greater deposition temperature, bring on the film surface become more homogeneous, so aggregate will be reduced and the gelatin process accur in quickly and made the particle tied on glass substrate first before its spread. The process of layer fabrication was influent by low rate of conventional spin-coater.

The thickness of thin film can be determined by SEM figure 3 (b) and (d), where in transverse position (crosssection) at 2000 times magnification the average of thickness is $\pm 3,4 \mu \mathrm{m}$ (ITO-Al) and $0.974 \mu \mathrm{m}$ (ITO-ZnO). Cheong was reported in general the thin layer have 100-200 nm thickness(6). It was indicated that formation of thin layer is thick. The thicker thin layer was produced will make the decreasing of thin layer transmittance.

The results of measurements on thin-layer ITO multimeter without doping are shown in Table 1. 
Table 1. Effect times coating for resistence of ITO

\begin{tabular}{|c|c|}
\hline Times coating & $\begin{array}{c}\text { Resintance }\left(\mathrm{k} \Omega / \mathrm{cm}^{2}\right) \\
\text { Of ITO }\end{array}$ \\
\hline 1 & $10^{5}$ \\
\hline 2 & 1689.573 \\
\hline 3 & 22.011 \\
\hline 4 & 9.331 \\
\hline 5 & 11.796 \\
\hline
\end{tabular}

From the data were obtained, optimum coating on a thin layer of ITO at 4 times coating where it has the resistance value $9.331 \mathrm{k} \Omega / \mathrm{cm} 2$, so 4 and 5 layers can be referable in layers variation to determine the effect of doping for ITO conductivity. The measurement results of ITO thin layer with Al doping 5\% are shown in Table 2.

Table 2. Measurement of resistance of 4 and 5 times coating for ITO-Al and ITO-ZnO

\begin{tabular}{|c|c|c|c|c|}
\hline $\begin{array}{c}\text { Dopant concentration } \\
(\% \mathrm{w} / \mathrm{v})\end{array}$ & $\begin{array}{c}\text { Resistance of } \\
4 \text { times coating } \\
\left(\mathrm{k} \Omega / \mathrm{cm}^{2}\right) \\
(\mathrm{Al} \text { dopant })\end{array}$ & $\begin{array}{c}\text { Resistance of } \\
5 \text { times coating } \\
\left(\mathrm{k} \Omega / \mathrm{cm}^{2}\right) \\
(\mathrm{Al} \mathrm{dopant})\end{array}$ & $\begin{array}{c}\text { Resistance of } \\
5 \text { times coating } \\
\left(\mathrm{k} \Omega / \mathrm{cm}^{2}\right) \\
(\mathrm{ZnO} \text { dopant })\end{array}$ & $\begin{array}{c}\text { Resistance of } \\
5 \text { times coating } \\
\left(\mathrm{k} \Omega / \mathrm{cm}^{2}\right) \\
(\mathrm{ZnO} \text { dopant })\end{array}$ \\
\hline 0 & 9.331 & 11.79 & 9.3 & 11.8 \\
\hline 1 & 31.95 & 35.9 & 4740 & 312100 \\
\hline 3 & 50.7 & 57.50 & 12760 & 264000 \\
\hline 5 & 17 & 1271 & 6070 & 80800 \\
\hline
\end{tabular}

When compared to the conductivity of a thin layer ITO-Al coating between 4 and 5 layers the coating, it can be seen that the constraints generated by a thin layer with 4 times coating the coating has a lower barrier than 5 layers the coating. This is caused of the greater number of layers to achieve the optimum conditions the better electrical, the highest conductivity of thin film at 4 times coating with $\mathrm{Al}$ doping $5 \%$ the result is $17 \mathrm{k} \Omega / \mathrm{cm}^{2}$. The addition effect of the addition of $\mathrm{Al}$ and $\mathrm{ZnO}$ doping on the electrical resistance value of ITO thin film can be described in Figure 4.
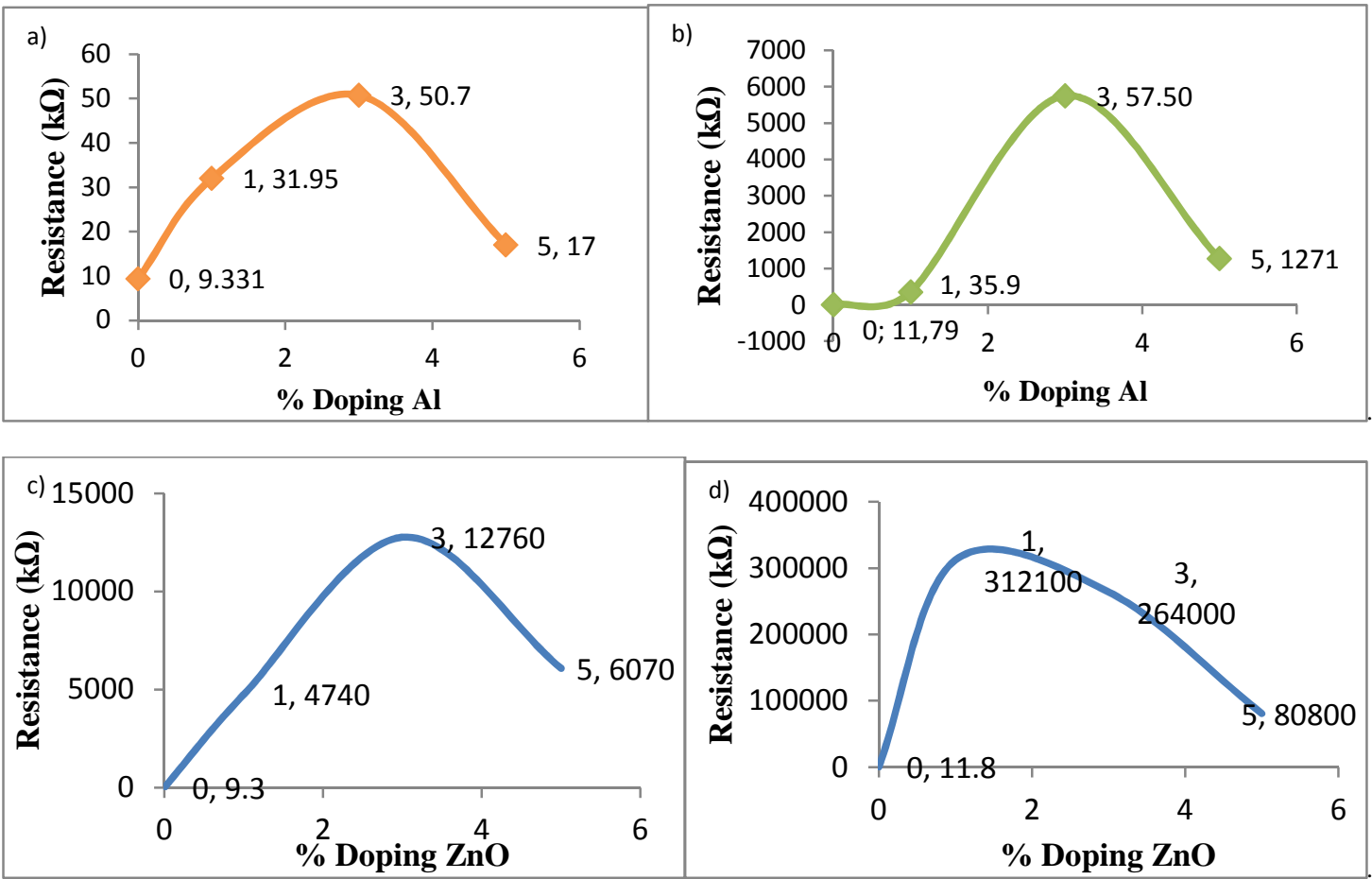

Figure 4. Resistance thin layer of ITO-Al a) 4 times coating, b) ITO-Al 5 times, and thin layer of ITO-ZnO c) 4 times coating and d) 5 timess coating

The fabrication of a thin layer of ITO-Al 5\% have been successfully carried out, but the resulting electrical conductivity was low. In general, addition of doping will increase the conductivity of ITO. Sistesya reported this is caused by decreasing the band gap of material for excitation of electron (15). Caused by addition of the band gap, it 
will make the band gap became small and the photon energy for excite the electron will decrease, and the conductivity will increase. ITO have $3.5 \mathrm{eV}$ band gap, and $\mathrm{ZnO}$ have $3.37 \mathrm{eV}$ band gap.

Based on Figure 4, addition $\mathrm{ZnO}$ doping $(1 \%)$ can decrease the conductivity from $9.331 \mathrm{k} \Omega / \mathrm{cm}^{2}$ to $4.74 \mathrm{k} \Omega / \mathrm{cm}^{2}(4$ times coating), but after 5 times coating decrease to $6.070 \mathrm{k} \Omega / \mathrm{cm}^{2}$. Formation of ITO-ZnO thin layer make the low conductivity, because modified spin-coater from magnetic stirrer have low spin (500 rpm). According Kesim, to make good thin film with the $1.5 \mathrm{k} \Omega / \mathrm{cm}^{2}$, we need spin velocity is $1000 \mathrm{rpm}(20)$. The high anguler velocity from spin coater will make distribution of matter homogenously and will increase the optical and electrical properties.

Effect of calcination in innert condition is improve formation of material. In this case, $\mathrm{N} 2$ gas will make sinthesis in innert condition so that the formation thin layer will free from contaminants. N2 gas will be function initiate ITO percusor formation. Beside that, $\mathrm{InCl} 3.4 \mathrm{H} 2 \mathrm{O}$ is high hygroscopic, so that will change bacame oxide metal when contact with atmosphere. In First mixing the material with dopants, there is not forming the valency between ITO and dopants, but only heteregenously mixture. This is indicated that $\mathrm{ZnO}$ is an isolator for ITO. An was reported that formation ITO thin layer under flow $\mathrm{N}_{2}$ gas by calcination was considerated by increasingly of oxygen vacancy concentration. It will make increase the charge carrier concentration and electrical conductivity was produced (3). Zainul et al reported that effect of calcination temperature in formation $\mathrm{Cu}_{2} \mathrm{O} / \mathrm{CuO}$ which after calcination at $400{ }^{\circ} \mathrm{C}$ was obtained percent oxygen is $16.5 \%$ and $500^{\circ} \mathrm{C}$ percent oxygen on the surface of the $\mathrm{Cu}$ plate is $15.27 \%$. Increasing of oxygen on the surface of the plate, will lead to an increase in the photocatalytic ability of the semiconductor material, since the formation of the conduction band(25).

\section{CONCLUSION}

This research has successfully to made a thin layer of ITO-Al dan ITO-ZnO with Spin-coating technique through Sol-Gel process, this is evidenced by the characterization of XRD, SEM and Multimeter. The optimum coating on a thin layer of ITO-Al accure at 4 times coating with the addition of 5\% $\mathrm{Al}$ doped with electrical resistance generated is $17 \mathrm{k} \Omega / \mathrm{cm}^{2}$.The value of electrical resistance of ITO layer is lower than the value of the electrical resistance of a thin layer of ITO-Al 5\%, the doping of Al tends to lower the electrical conductivity of ITO glass. This indicates that the doping is less suitable to the ITO glass. The ITO thin film have smaller resistance than the ITO doped ZnO thin film. Doping ZnO tend to lower the value of the electrical conductivity of ITO material. Better conditions of the preparation of ITO doped $\mathrm{ZnO}$ thin film was 5 layers by the addition of $5 \%$ doping $\mathrm{ZnO}$ with resistance $80.8 \mathrm{k} \Omega$ $/ \mathrm{cm} 2$.

\section{REFERENCES}

[1] Ding Z. 2010. Journal of Nanomaterial. 2010:1-5

[2] Alam MJ, D.C.Cameron. 2000.455-9

[3] Skjaervo HS. 2013. Disertation. Norwegian University of Science and Technology

[4] Ogi T. 2006. Journal of Nanoparticle Research:343-50

[5] Helen SS. 2013. Norwegian : University of Science and technology Department of Meterial Science and Enegineering.

[6] Cheong D. 2011. Journal of the Korean Ceramic Society 48:516-9

[7] Gareso LP. 2012. Fisika Semikonduktor. Makassar: Lembaga Kajian dan Pengembangan Pendidikan

[8] Zainul R, Alif A, Aziz H, Arief S, Dradjad S, Munaf E. 2015. Research Journal of Pharmaceutical, Biological and Chemical Sciences 6(4):353-61

[9] Sistesya D, Susanto H. 2013. Youngster Physics Journal 1:71-80

[10] Suprayogi D. 2014. Jurnal Fisika 3:19-26

[11]Lupan O. 2009. Solar Energy Materials \& Solar Cells:1417-22

[12] Rosa ES. 2009. Jurnal Elektronika, Bandung, UPI 9

[13] Sueta N. 2008. Thesis. FMIPA. University of Indonesia

[14] Hoong LJ. 2013. International Journal of Emerging Trends in Engineering and Development 4:496-501

[15] Daoudi K. 2002. Material Science and Engineering:313-7

[16] Kim S-M. 2009. Journal of the Korean Physical Society 55:1996-2001

[17] Stoica TF. 2008. Journal of Optoelectronics and Advanced Materials 2:684-8

[18] Yang YR. 2012. Research Article:1-7

[19] Brinker C, J. 1991. Thin Solid Films:97-108

[20] Kesim MT. 2012. Thesis. Middle East Technical University

[21] Adem U. 2003. Thesis. Middle East Technical Univeristy

[22] Saputra RI. 2012. Jurnal Teknik Pomits 1:1-3

[23] Yang LL. 2009. Thin Solid Films:4979-83

[24] Maddu A. 2006. Jurnal Sains Materi Indonesia 7:85-90 
[25]Zainul R, Alif A, Aziz H, Yasthopi A, Arief S, Syukri. 2015. Journal of Chemical and Pharmaceutical Research 7(11):57-67 